\title{
APPLIED ECONOMETRICS RANKINGS: 1989-1995
}

\author{
BADI H. BALTAGI* \\ Department of Economics, Texas A\&M University, College Station, Texas 77843-4228, USA
}

\begin{abstract}
SUMMARY
This paper ranks academic institutions by publication activity in applied econometrics over the period 1989-1995. Fourteen leading international journals that publish applied econometrics articles are used to provide the database. The rankings are based on standardized page counts of articles published in these journals over the stated period. A 'Hall of Fame' is developed listing the top 100 individual producers of applied econometrics in the fourteen journals considered. To control for quality differences among the applied journals, separate rankings are provided both for institutions and for individuals according to econometrics publications by journal. Copyright (C) 1999 John Wiley \& Sons, Ltd.
\end{abstract}

\section{INTRODUCTION}

Recent studies ranking institutions in the field of economics include Hirsch et al. (1984), Bairam (1994), Conroy and Dusansky (1995), Scott and Mitias (1996) and Dusansky and Vernon (1998). ${ }^{1}$ For rankings in econometrics, see Hall $(1987,1990)$ for the period $1980-1985$ and 1980 1988 and Baltagi (1998) for the period 1989-1995. The latter ranking is based on standardized page counts of articles published in theoretical and all econometrics contributions in fifteen leading journals. This paper uses the same database in Baltagi (1998) to provide worldwide rankings of academic institutions based on their research activity in applied econometrics over the period 1989-1995. In addition, an 'Applied Econometrician Hall of Fame' list is developed. This list includes the top 50 individual producers in terms of standardized page counts in applied econometrics over the period 1989-1995.

\section{DATABASE}

This paper focuses on research articles in applied econometrics published in the following journals: American Economic Review, Econometrica, Econometric Reviews, Economic Journal, International Economic Review, Journal of the American Statistical Association, Journal of Applied Econometrics, Journal of Business and Economic Statistics, Journal of Econometrics, Journal of Monetary Economics, Journal of Political Economy, Journals of the Royal Statistical Society, Review of Economics and Statistics, and Review of Economic Studies. These are the same journals used by Baltagi (1998) except for Econometric Theory, which had no applied econometrics articles. Affiliations with academic institutions were recorded as they appeared in the published article, and in case of $n$ joint authors, each author was assigned $(1 / n)$ of the publication credit. Historical remarks, software and book reviews and interviews were also excluded. Next, each econometrics article was classified as theoretical or applied. For general journals like the

* Correspondence to: Badi Baltagi, Dept of Economics, Texas A\&M University, College Station, TX 77843-4228, USA. E-mail: Badi@econ.tamu.edu

${ }^{1}$ For rankings in statistics, see Phillips, Choi and Schochet (1988).

CCC 0883-7252/99/040423-19\$17.50

Received 4 August 1998

Copyright (C) 1999 John Wiley \& Sons, Ltd.

Revised 15 December 1998 
American Economic Review and Journal of Political Economy, the articles with no substantial econometrics content were dropped from the database. ${ }^{2}$ Page counts were standardized according to the average number of characters published on one page of the respective journal. The numeraire was set as $1.00=$ Econometrica.

Table I lists the 15 journals, the total number of authors, articles, and standardized pages attributed to academic institutions for all econometrics publications and applied econometrics publications. The last column gives the conversion factors used to standardize the page counts. These are the same conversion factors used by Hall $(1987,1990)$ and Baltagi (1998). In the complete database, there were 3477 articles attributed to 5991 authors and 600 academic institutions with a total of 61,415 standardized pages (see Baltagi, 1998). For applied econometrics, there were 2390 articles attributed to 4247 authors and 514 academic institutions with a total of 40,837 standardized pages. These articles correspond to 2415 distinct authors. From Table I, it is clear that a high percentage of the applied econometrics standardized pages appear in the Review of Economics and Statistics (16\%), American Economic Review (15\%), Journal of Business and Economic Statistics (11\%), Journal of Political Economy (10\%), Journal of Monetary Economics (9\%), Journal of Econometrics (9\%), Economic Journal (8\%) and Journal of Applied Econometrics (7\%). Seven of these journals have more than $75 \%$ of their standardized pages in econometrics devoted to applied work. To control for quality differences among journals and the conversion factors used, we also rank universities by journal.

\section{RANKINGS USING APPLIED ECONOMETRICS CONTRIBUTIONS}

Table II ranks the top 150 academic institutions based on their contributions in applied econometrics. The ranking is based on the total standardized page count published by individuals associated with these institutions for the period 1989-1995. This is compared with Baltagi's (1998) econometrics theory and all econometrics rankings for the same period. Also included are the rankings for the field of economics as a whole for the period 1984-1993 published by Scott and Mitias (1996). ${ }^{3}$

The University of Chicago is number one in applied econometrics, even though it is ninth in econometric theory and second in economics and all econometrics. The University of Pennsylvania is second in applied econometrics even though it is twenty-eighth in econometric theory, fifth in all econometrics and third in economics. In general, the applied econometrics rankings agree more with the econometrics rankings than with the economics rankings or the theoretical econometrics rankings.

Over the period 1989-1995, a total of 53 Econometrica equivalent pages in applied econometrics were needed to rank a university in the 150 range. It takes only 36 more pages to move from 150 to 100 . As expected, the climb becomes steeper, requiring 128 extra pages to get into the 50 range and 132 more pages to move from rank 50 to rank 25. From rank 25 to rank 10 an additional 269 pages are needed, and from rank 10 to rank 1 another 571 pages are needed.

\footnotetext{
${ }^{2}$ The 'applied econometrics' classification is subjective. As one referee points out, there is a significant difference between 'applied or empirical economics' and 'applied econometrics'. Applied econometrics must be of substantive economic and methodological econometric interest, whereas applied economics, although of substantive interest and empirical, often simply uses off-the-shelf econometrics.

${ }^{3}$ These are based on publications in 36 leading economic journals that have 10 journals in common with the 14 applied econometrics journals. Unfortunately, these economic rankings exclude non-US academic institutions.
} 
Table I. Data summary, 1989-1995

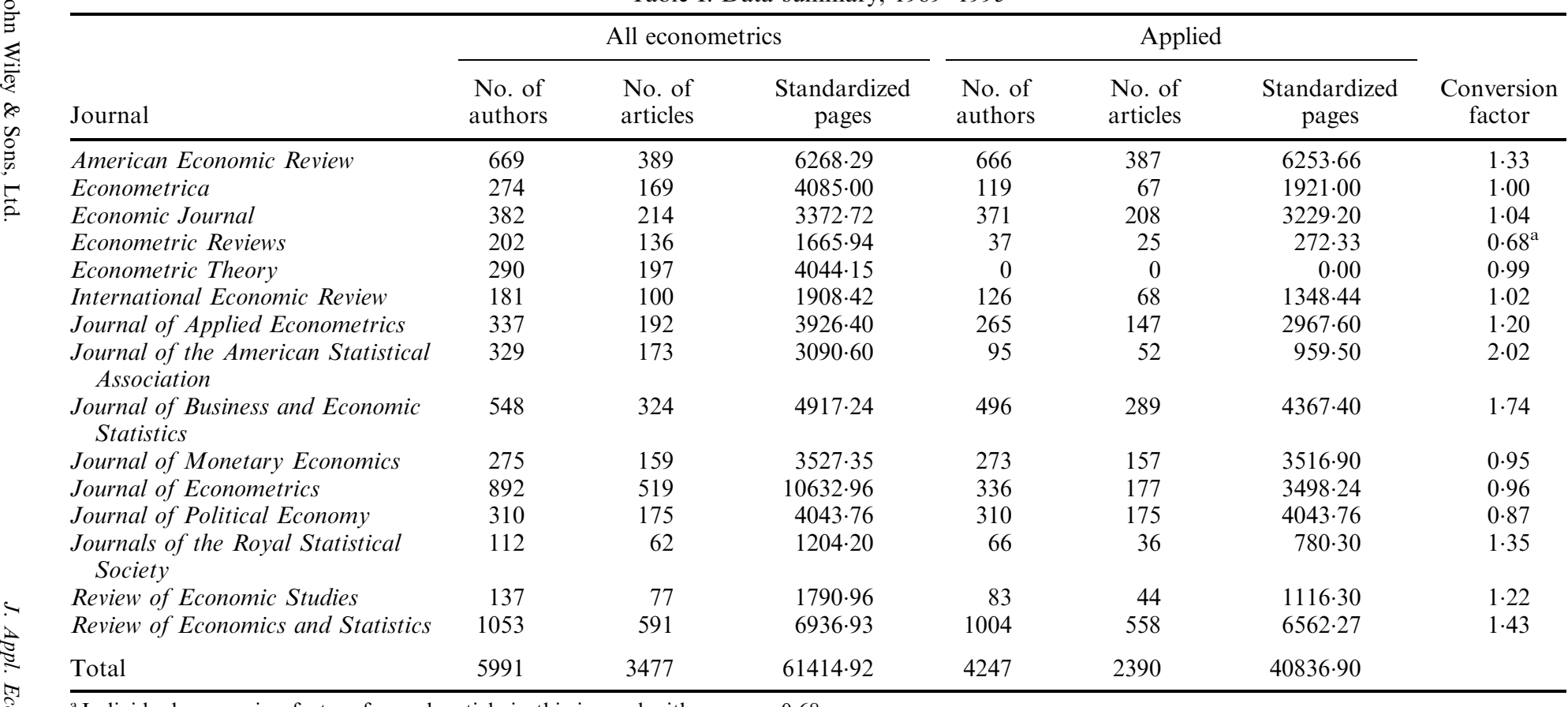

${ }^{\mathrm{a}}$ Individual conversion factors for each article in this journal with mean $=0.68$. 
Table II. Ranking of institutions by applied econometrics publications, 1989-1995

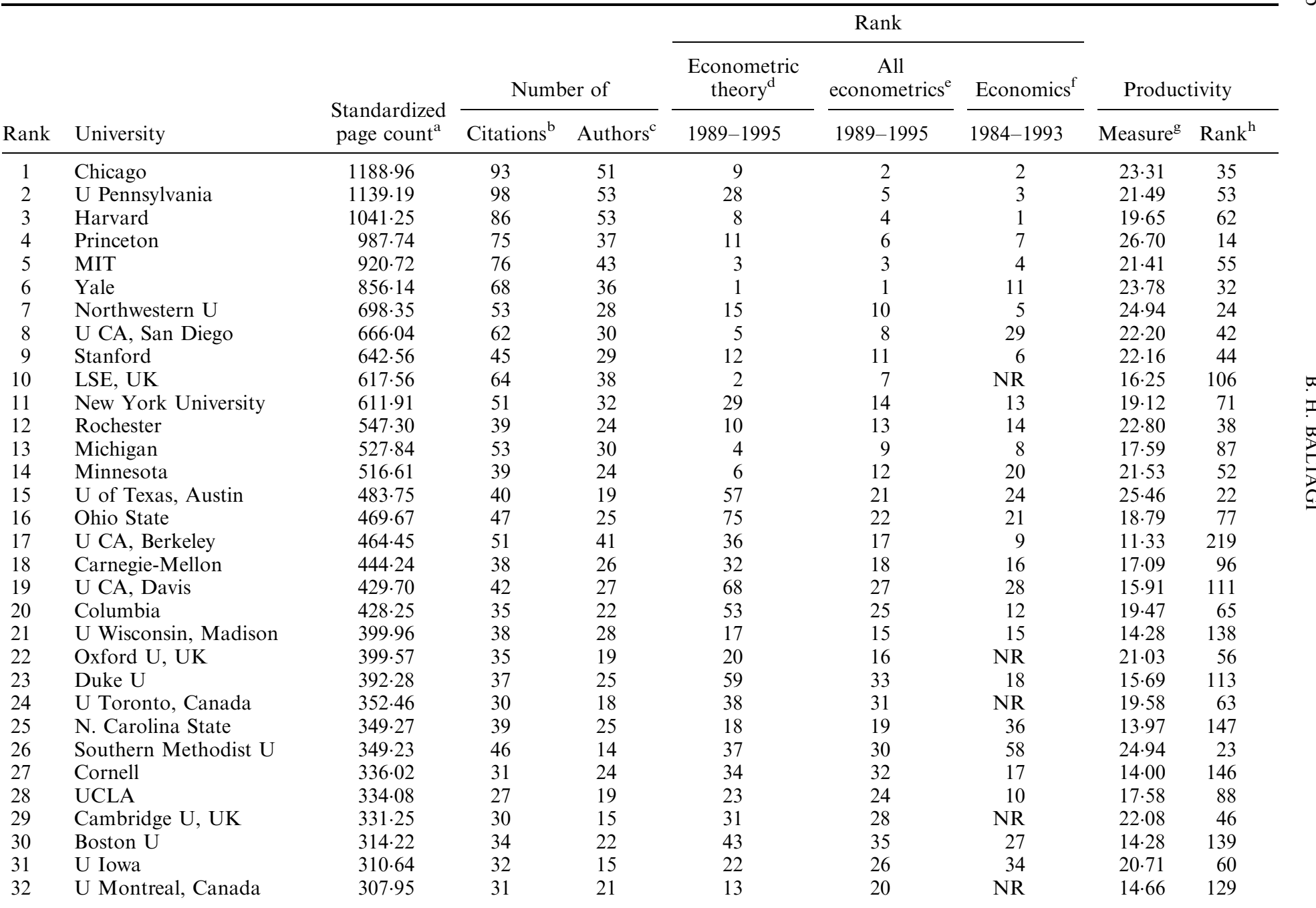


U British Columbia,

$302 \cdot 64$

25
20
31
39
25
22
30
25
27
24
28
28
22
17

17

46

Canada

Penn State U

Texas A\&M University

$299 \cdot 07$

U Florida

288.30

U Southern California $\quad 263.69$

U Illinois, Urbana $\quad 261.66$

U Pittsburgh

Indiana $\mathrm{U}$

U Warwick, UK

$259 \cdot 16$

U College, London

McMaster U, Canada

U Houston

U North Carolina,

Chapel Hill

U Maryland

Michigan State

U York, UK

Tilburg U, Netherlands

Tel Aviv U

Brown

Rutgers

Queen's U, Canada

U Washington

U Amsterdam,

Hebrew U, Jerusalem

Iowa State

U Georgia

Arizona State U

Erasmus U, Netherlands

Birkbeck College, UK

U Essex, UK

U CA, Santa Barbara

SUNY, Stony Brook

$250 \cdot 8$

241.93

239.58

232.51

226.41

222.75

$222 \cdot 24$

$221 \cdot 60$

$216 \cdot 89$
$210 \cdot 32$

$205 \cdot 03$

$201 \cdot 18$

198.72

$194 \cdot 58$

179.90

$179 \cdot 27$

$175 \cdot 94$

175.87

$170 \cdot 62$

$170 \cdot 47$

$157 \cdot 83$

$156 \cdot 87$

154.96

153.87

U Limburg, Netherlands

Vanderbilt 
Table II (Continued)

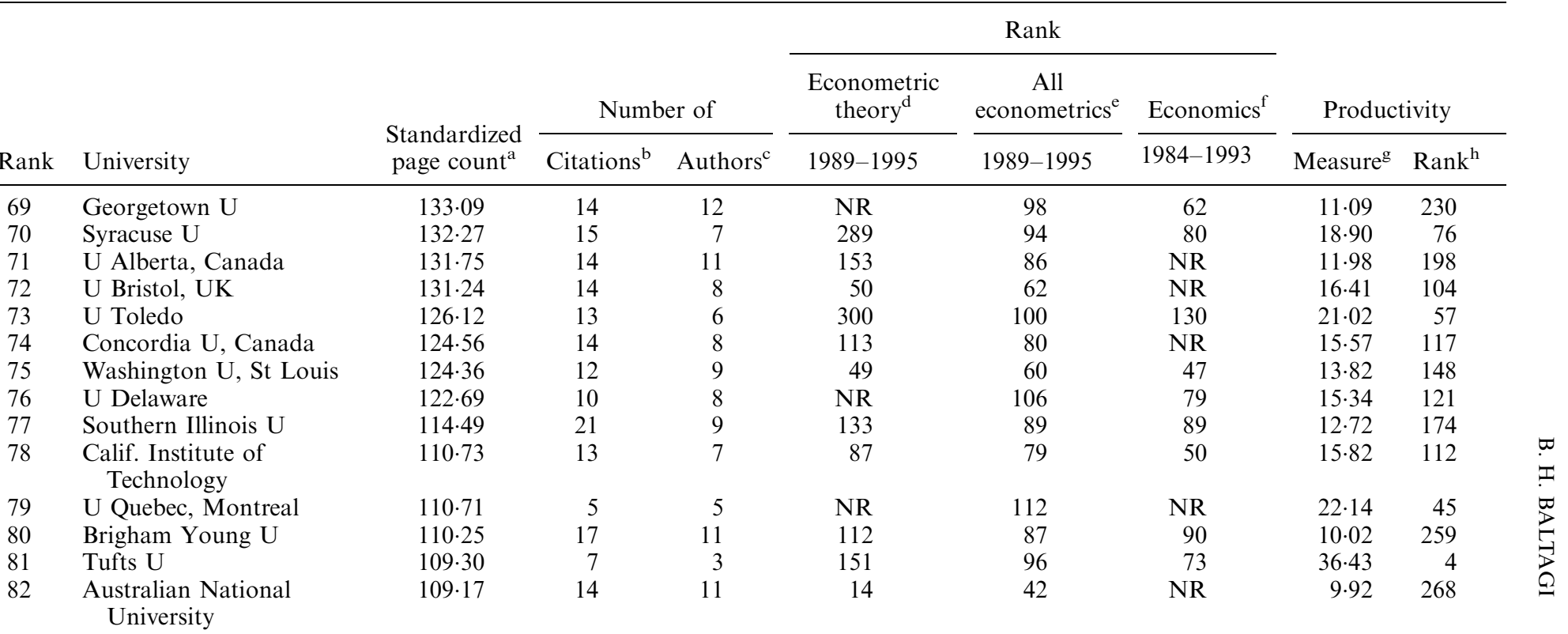

NSEE, France

Brandeis U

$105 \cdot 29$

Free U, Amsterdam

Clemson U

Florida State U

U Melbourne, Australia

$103 \cdot 99$

$102 \cdot 72$

102.22

99.90

U Western Ontario,

99.90

Canada

90 Boston College

Georgia State U

U Arizona

$99 \cdot 07$

98.50

$96 \cdot 87$

Louisiana State U

Stockholm U

93.78

92.08

U Groningen, Netherlands $\quad 91.09$

$90 \cdot 24$

American University

89.64

8
10
14
17
12
7
9

13
13
15
17
7
7
5
10

4

21

82

66
234
65

65

160

NR $\quad 26.32 \quad 17$

$\begin{array}{lll}94 & 20.82 & 58\end{array}$

NR $\quad 13.00 \quad 16$

$\begin{array}{rrr}56 & 9.34 & 290 \\ 63 & 12.78 & 171\end{array}$

$\begin{array}{lrr}\text { NR } & 19.98 & 61 \\ \text { NR } & 14.18 & 143\end{array}$

86
190
139
167
NR
54
25
229

$\begin{array}{rrr}55 & 9 \cdot 01 & 309 \\ 83 & 12 \cdot 31 & 184 \\ 49 & 8 \cdot 07 & 335 \\ 38 & 6 \cdot 70 & 392 \\ \text { NR } & 18 \cdot 42 & 79 \\ \text { NR } & 22 \cdot 77 & 40 \\ \text { NR } & 45 \cdot 12 & 2 \\ 127 & 14 \cdot 94 & 127\end{array}$




\begin{tabular}{|c|c|c|}
\hline & 98 & Virginia Polytech U \\
\hline g & 99 & $\mathrm{U}$ of California, Irvine \\
\hline & 100 & Williams College \\
\hline & 101 & City U, London \\
\hline & 102 & Dartmouth College \\
\hline & 103 & U Notre Dame \\
\hline & 104 & SUNY, Buffalo \\
\hline & 105 & Johns Hopkins U \\
\hline & 106 & $\begin{array}{l}\text { Queen Mary College, } \\
\text { London }\end{array}$ \\
\hline & 107 & SUNY, Albany \\
\hline & 108 & Northern Illinois U \\
\hline & 109 & Carleton U, Canada \\
\hline & 110 & Montana State U \\
\hline & 111 & Aarhus U, Denmark \\
\hline & 112 & U Wisconsin, Milwaukee \\
\hline & 113 & Uppsala U, Sweden \\
\hline & 114 & U South Carolina \\
\hline & 115 & U Western Australia, Perth \\
\hline & 116 & U Illinois, Chicago \\
\hline & 117 & Emory U \\
\hline & 118 & Korea U \\
\hline & 119 & Nat. U Singapore \\
\hline & 120 & U Oregon \\
\hline & 121 & U New Mexico \\
\hline & 122 & $\begin{array}{l}\text { U Newcastle Upon Tyne, } \\
\text { UK }\end{array}$ \\
\hline & 123 & Auburn U \\
\hline & 124 & U Texas, Dallas \\
\hline & 125 & Rice U \\
\hline & 126 & U Sydney, Australia \\
\hline & 127 & George Mason U \\
\hline & 128 & U Hull, UK \\
\hline & 129 & U Geneva, Switzerland \\
\hline & 130 & U Padova, Italy \\
\hline & 131 & U California, Santa Cruz \\
\hline & 132 & U Glasgow \\
\hline & 133 & U Kentucky \\
\hline
\end{tabular}

\begin{tabular}{|c|c|c|c|c|c|c|c|}
\hline 89.13 & 8 & 8 & 42 & 69 & 41 & 11.14 & 226 \\
\hline 88.99 & 13 & 8 & 83 & 88 & 57 & $11 \cdot 12$ & 227 \\
\hline 88.95 & 12 & 8 & NR & 135 & 128 & $11 \cdot 12$ & 228 \\
\hline 88.37 & 14 & 11 & NR & 137 & NR & 8.03 & 336 \\
\hline $88 \cdot 26$ & 8 & 4 & NR & 138 & 52 & $22 \cdot 06$ & 47 \\
\hline 85.79 & 7 & 4 & 180 & 115 & 104 & 21.45 & 54 \\
\hline 83.29 & 12 & 10 & 207 & 125 & 69 & 8.33 & 329 \\
\hline $83 \cdot 12$ & 9 & 8 & 197 & 123 & 48 & $10 \cdot 39$ & 252 \\
\hline 82.78 & 7 & 5 & NR & 145 & NR & $16 \cdot 56$ & 103 \\
\hline $81 \cdot 16$ & 11 & 7 & 146 & 113 & 71 & 11.59 & 206 \\
\hline $80 \cdot 00$ & 8 & 5 & 176 & 120 & 111 & $16 \cdot 00$ & 110 \\
\hline 79.94 & 6 & 3 & 285 & 140 & NR & $26 \cdot 65$ & 15 \\
\hline 78.91 & 6 & 3 & NR & 150 & 99 & $26 \cdot 30$ & 18 \\
\hline 73.67 & 6 & 3 & 88 & 97 & NR & 24.56 & 29 \\
\hline 73.02 & 10 & 8 & 89 & 99 & 88 & 9.13 & 304 \\
\hline $72 \cdot 47$ & 8 & 6 & 161 & 126 & NR & $12 \cdot 08$ & 196 \\
\hline $70 \cdot 73$ & 11 & 7 & NR & 161 & 78 & $10 \cdot 10$ & 257 \\
\hline 69.97 & 6 & 3 & 125 & 114 & NR & $23 \cdot 32$ & 34 \\
\hline $69 \cdot 34$ & 8 & 6 & NR & 163 & 66 & 11.56 & 209 \\
\hline 68.00 & 5 & 5 & 128 & 117 & 82 & 13.60 & 150 \\
\hline $66 \cdot 28$ & 4 & 2 & NR & 166 & NR & $33 \cdot 14$ & 6 \\
\hline $66 \cdot 15$ & 9 & 7 & 158 & 131 & NR & $9 \cdot 45$ & 282 \\
\hline $65 \cdot 55$ & 9 & 7 & 220 & 152 & 60 & $9 \cdot 36$ & 283 \\
\hline $65 \cdot 11$ & 5 & 4 & NR & 168 & 123 & $16 \cdot 28$ & 105 \\
\hline $64 \cdot 81$ & 7 & 4 & NR & 169 & NR & $16 \cdot 20$ & 107 \\
\hline $64 \cdot 25$ & 15 & 9 & 243 & 157 & 81 & $7 \cdot 14$ & 379 \\
\hline 63.83 & 7 & 5 & 186 & 142 & 103 & 12.77 & 172 \\
\hline $63 \cdot 54$ & 8 & 5 & 35 & 70 & 75 & 12.71 & 175 \\
\hline $63 \cdot 17$ & 8 & 6 & 81 & 101 & NR & 10.53 & 248 \\
\hline 63.07 & 9 & 7 & 211 & 154 & 51 & 9.01 & 308 \\
\hline $62 \cdot 60$ & 7 & 5 & NR & 174 & NR & 12.52 & 179 \\
\hline $62 \cdot 37$ & 6 & 4 & 152 & 136 & NR & 15.59 & 116 \\
\hline $60 \cdot 98$ & 5 & 4 & 145 & 134 & NR & $15 \cdot 24$ & 122 \\
\hline $60 \cdot 49$ & 7 & 5 & 238 & 159 & 91 & $12 \cdot 10$ & 195 \\
\hline 59.67 & 10 & 8 & 252 & 164 & NR & $7 \cdot 46$ & 363 \\
\hline 59.48 & 6 & 5 & 107 & 116 & 61 & 11.90 & 201 \\
\hline
\end{tabular}




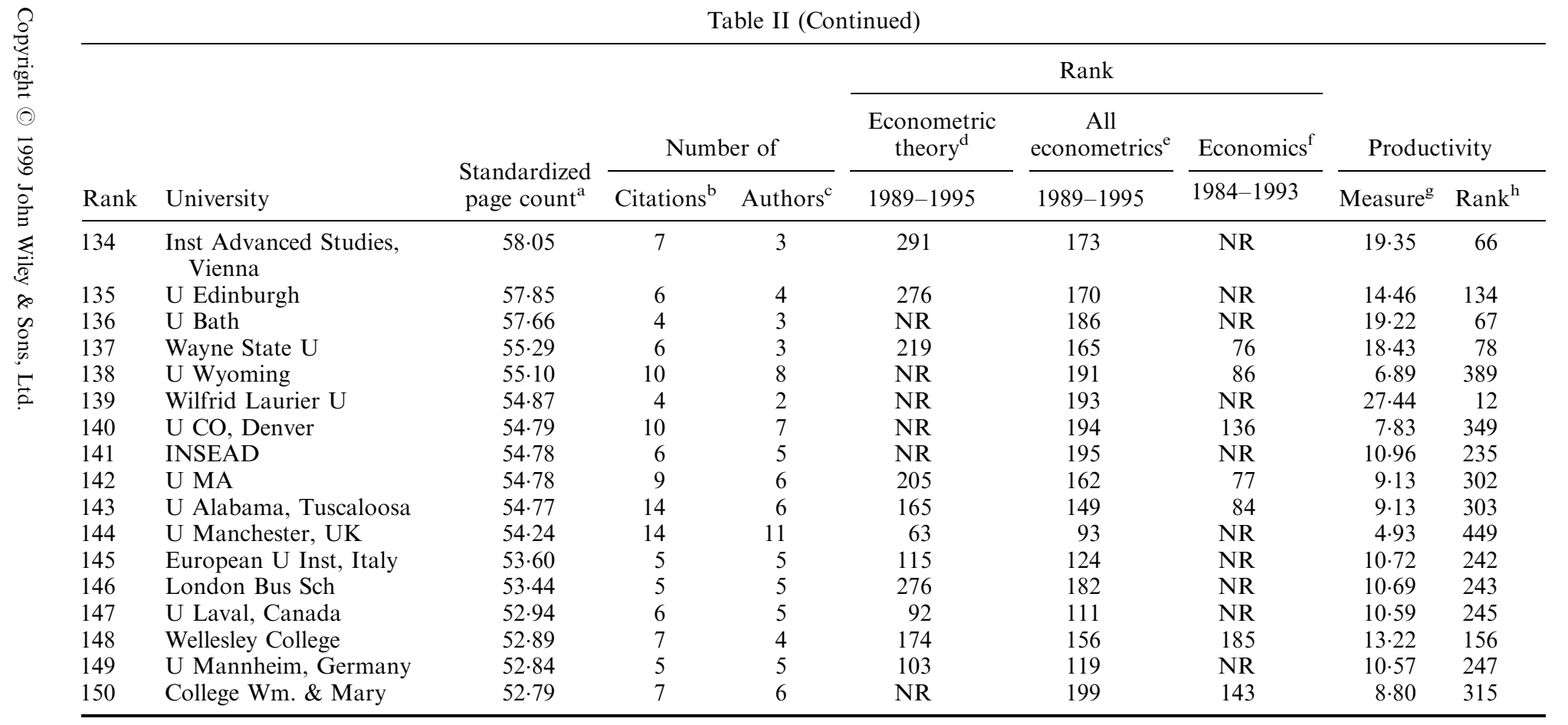

a Standardized page count in applied econometrics based on the 14 journals listed in Table I.

${ }^{b}$ Number of applied econometrics articles published in the 14 journals listed in Table I

${ }^{\mathrm{c}}$ Number of distinct authors publishing in applied econometrics in the 14 journals listed in Table I.

${ }^{\mathrm{d}}$ The 1989-1995 econometric theory rankings are given in Baltagi (1998).

The 1989-1995 all econometrics rankings are given in Baltagi (1998).

The 1984-1993 rankings for the field of economics are given in Scott and Mitias (1996).

${ }^{\mathrm{g}}$ The productivity measure is obtained by dividing the standardized page count by the number of authors.

${ }^{\mathrm{h}}$ This ranks institutions by their productivity measure. 
Included in Table II is the number of standardized pages per contributing author as a crude estimate of productivity for each institution. The last column gives the corresponding productivity rank. Although the latter measure has its limitations, it does point out institutions whose ranking is high solely because of the high productivity of one or two econometricians. For example, the University of Copenhagen is second by this productivity measure due to the productivity of Katarina Juselius and Soren Johansen. This measure penalizes universities with many contributors such as Chicago, which drops from 1 to 35 , the University of Pennsylvania which drops from 2 to 53, and Harvard which drops from 3 to 62 .

The big gainers from comparing rankings in economics with those in applied econometrics include: Yale which is eleventh in economics and sixth in applied econometrics; UC-San Diego, which ranks twenty-ninth in economics and eighth in applied econometrics; Minnesota, which ranks twentieth in economics and fourteenth in applied econometrics; North Carolina State, which ranks thirty-sixth in economics and twenty-fifth in applied econometrics; University of Texas at Austin, which ranks twenty-fourth in economics and fifteenth in applied econometrics. Losers from such comparisons include: Michigan, which drops from eighth in economics to thirteenth in applied econometrics; Berkeley, which drops from ninth in economics to seventeenth in applied econometrics; UCLA, which drops from tenth in economics to twentyeighth in applied econometrics, and Columbia which drops from twelfth in economics to twentieth in applied econometrics.

\section{THE APPLIED ECONOMETRICIANS' HALL OF FAME}

In this section, the focus is on the applied econometrician themselves and their productivity over the period 1989-1995. Table III lists the top 50 individual publishers in applied econometrics in the 14 journals considered from 1989 to 1995, their institutional affiliation as it appears on their most current article, the number of articles published, and the total standardized page count for each author. More than 68 Econometrica equivalent pages were required to belong to this top 50 list. The top 25 individuals published more than 86 Econometrica equivalent pages over the period 1989-1995, which is more than 12 pages per year.

Table IV gives an alternative ranking of individuals based on the number of articles published in applied econometrics in the 14 journals considered over the period 1989-1995. This ranking does not penalize multiple authors like the ranking in Table III. However, the ranking does not control for article length or for differences among journals. ${ }^{4}$ Table IV lists 58 individuals who had six or more applied econometrics articles in our database. The number of standardized pages is given along with the corresponding rank obtained from Table III. Robert Engle, who has 12 applied articles, is second in this ranking but nineteenth by the standardized page count. Dan Slottje, who has 11 applied articles, is third in this ranking but forty-third by the standardized page count. Similarly, Hashem Pesaran, who has 10 applied articles, is fifth in this ranking but twelfth by the standardized page count, and Richard Blundell, who has 10 applied articles, is sixth in this ranking but fifty-third by the standardized page count. Clive Granger, who has 10 applied articles, is seventh in this ranking but sixtieth according to the standardized page count.

\footnotetext{
${ }^{4}$ As one referee suggests, think of an 'article' as an 'idea'. Table IV ranks individuals by the number of applied econometrics ideas in the 14 journals listed in Table I. 
Table III. Ranking of individuals by applied econometrics publications, 1989-1995

\begin{tabular}{|c|c|c|c|c|}
\hline Rank & Author & University & $\begin{array}{l}\text { Standardized } \\
\text { pages }^{\mathrm{a}}\end{array}$ & $\begin{array}{l}\text { Number of } \\
\text { articles }\end{array}$ \\
\hline 1 & Slesnick, Daniel T. & U TX, Austin & $186 \cdot 097$ & 10 \\
\hline 2 & Rosenzweig, Mark R. & $\mathrm{UPA}$ & $180 \cdot 590$ & 15 \\
\hline 3 & Angrist, Joshua D. & Hebrew U, Jerusalem & $145 \cdot 490$ & 9 \\
\hline 4 & Deaton, Angus S. & Princeton & $138 \cdot 585$ & 7 \\
\hline 5 & Lewis, Karen K. & $\mathrm{U}$ PA & $130 \cdot 630$ & 6 \\
\hline 6 & Campbell, John Y. & Princeton & 128.635 & 8 \\
\hline 7 & Heckman, James J. & U Chicago & $124 \cdot 140$ & 9 \\
\hline 8 & Canova, Fabio & U Pompeu Fabra, Barcelona & $122 \cdot 240$ & 7 \\
\hline 9 & Koop, Gary & U Toronto & $115 \cdot 080$ & 9 \\
\hline 10 & Wolpin, Kenneth I. & NYU & $105 \cdot 080$ & 8 \\
\hline 11 & Morrison, Catherine J. & Tufts U & $102 \cdot 650$ & 5 \\
\hline 12 & Pesaran, M. Hashem & Cambridge & $101 \cdot 723$ & 10 \\
\hline 13 & Watson, Mark W. & Northwestern U & $98 \cdot 955$ & 5 \\
\hline 14 & Buchinsky, Moshe & Yale & $98 \cdot 160$ & 2 \\
\hline 15 & Hendry, David F. & Oxford & 96.665 & 9 \\
\hline 16 & Poirier, Dale J. & U Toronto & 92.985 & 8 \\
\hline 17 & Fair, Ray C. & Yale & 92.635 & 7 \\
\hline 18 & Card, David & Princeton & 91.425 & 8 \\
\hline 19 & Engle, Robert F. & U CA, San Diego & $91 \cdot 235$ & 12 \\
\hline 20 & Baxter, Marianne & U VA, Charlottesville & 89.095 & 6 \\
\hline 21 & Ramey, Valerie A. & U CA, San Diego & $87 \cdot 645$ & 6 \\
\hline 22 & DeJong, David N. & U Pittsburgh & $86 \cdot 590$ & 8 \\
\hline 23 & Attanasio, Orazio $\mathrm{P}$ & Stanford U & 85.985 & 6 \\
\hline 24 & Browning, Martin & McMaster U & 85.968 & 7 \\
\hline 25 & van den Berg, Gerard J. & Free U, Amsterdam & $85 \cdot 580$ & 5 \\
\hline 26 & Viscusi, W. Kip & Duke U & $85 \cdot 178$ & 8 \\
\hline 27 & Nickell, Stephen J. & Oxford & 82.297 & 5 \\
\hline 28 & Griliches, Zvi & Harvard & 82.080 & 6 \\
\hline 29 & Meghir, Costas & U College, London & $81 \cdot 523$ & 7 \\
\hline 30 & Feenstra, Robert C. & U CA, Davis & $80 \cdot 373$ & 4 \\
\hline 31 & Gali, Jordi & NYU & $79 \cdot 760$ & 4 \\
\hline 32 & Perron, Pierre & Princeton & $79 \cdot 280$ & 4 \\
\hline 33 & Jacoby, Hanan G. & U Rochester & 77.070 & 4 \\
\hline 34 & Krueger, Alan B. & Princeton & 75.945 & 7 \\
\hline 35 & Eichenbaum, Martin & Northwestern U & $75 \cdot 645$ & 6 \\
\hline 36 & Kumbhakar, Subal C. & U TX, Austin & $75 \cdot 348$ & 8 \\
\hline 37 & Caballero, Ricardo J. & MIT & 74.898 & 5 \\
\hline 38 & Hoover, Kevin D. & U CA, Davis & 74.860 & 4 \\
\hline 39 & Hamermesh, Daniel S. & U TX, Austin & $74 \cdot 715$ & 6 \\
\hline 40 & Stewart, Mark B. & U Warwick & 74.030 & 6 \\
\hline 41 & Balke, Nathan S. & SMU & 72.970 & 5 \\
\hline 42 & Wadhwani, Sushil & LSE & $71 \cdot 600$ & 8 \\
\hline 43 & Slottje, Daniel J. & SMU & $70 \cdot 410$ & 11 \\
\hline 44 & Heaton, John & MIT & $70 \cdot 000$ & 2 \\
\hline 45 & Hardouvelis, Gikas A. & Rutgers U & 69.895 & 3 \\
\hline 46 & LeSage, James P. & U Toledo & $69 \cdot 587$ & 6 \\
\hline 47 & Shaw, Kathryn L. & CMU & $69 \cdot 105$ & 5 \\
\hline 48 & Paxson, Christina $\mathrm{H}$. & Princeton & 68.335 & 3 \\
\hline 49 & Alogoskoufis, George S. & Birkbeck College & $68 \cdot 017$ & 4 \\
\hline 50 & Burgess, Simon M. & U Bristol & $67 \cdot 880$ & 5 \\
\hline
\end{tabular}

${ }^{a}$ Standardized page count in applied econometrics based on the 14 journals listed in Table I.

${ }^{\mathrm{b}}$ Number of applied econometrics articles published in the 14 journals listed in Table I. 
Table IV. Ranking of individuals by the number of applied econometrics articles, 1989-1995

\begin{tabular}{rll}
\hline & & \\
Rank & Author & University \\
\hline 1 & Rosenzweig, Mark R. & U PA \\
2 & Engle, Robert F. & U CA, San Diego \\
3 & Slottje, Daniel J. & SMU \\
4 & Slesnick, Daniel T. & U TX, Austin \\
5 & Pesaran, M. Hashem & Cambridge \\
6 & Blundell, Richard W. & U College, London \\
7 & Granger, Clive W.-J. & U CA, San Diego \\
8 & Hayes, Kathy J. & SMU \\
9 & Angrist, Joshua D. & Hebrew U, Jerusalem \\
10 & Heckman, James J. & U Chicago \\
11 & Koop, Gary & U Toronto \\
12 & Hendry, David F. & Oxford \\
13 & Campbell, John Y. & Princeton \\
14 & Wolpin, Kenneth I. & NYU \\
15 & Poirier, Dale J. & U Toronto \\
16 & Card, David & Princeton \\
17 & DeJong, David N. & U Pittsburgh \\
18 & Viscusi, W. Kip & Duke U \\
19 & Kumbhakar, Subal C. & U TX, Austin \\
20 & Wadhwani, Sushil & LSE \\
21 & Deaton, Angus S. & Princeton \\
22 & Canova, Fabio & U Pompeu Fabra, Barcelona \\
23 & Fair, Ray C. & Yale \\
24 & Browning, Martin & McMaster U \\
25 & Meghir, Costas & U College, London \\
26 & Krueger, Alan B. & Princeton \\
27 & Gregory, Allan W. & Queen's U, Canada \\
28 & Harvey, Andrew C & LSE \\
29 & Neumark, David & Michigan State U \\
30 & Diebold, Francis X. & U PA \\
31 & Palm, Franz C. & U Limburg \\
32 & Grosskopf, Shawna & Southern IL U \\
33 & Formby, John P. & U Alabama, Tuscaloosa \\
34 & Bishop, John A. & E Carolina U, Greenville \\
35 & Lewis, Karen K. & U PA \\
36 & Baxter, Marianne & U VA, Charlottesville \\
37 & Ramey, Valerie A. & U CA, San Diego \\
38 & Attanasio, Orazio P. & Stanford U \\
39 & Griliches, Zvi & Harvard \\
40 & Eichenbaum, Martin & Northwestern U \\
41 & Hamermesh, Daniel S. & U TX, Austin \\
43 & Stewart, Mark B. & U Warwick \\
\hline 4 & LeSage, James P. & U Toledo \\
& Lewbel, Arthur & Brandeis U \\
Borjas, George J. & OH State U \\
\hline 75 Uevinsohn, James A. & LSE D Miego \\
\hline & &
\end{tabular}

\begin{tabular}{|c|c|c|}
\hline \multirow{2}{*}{$\begin{array}{l}\text { Article } \\
\text { count }^{\mathrm{a}}\end{array}$} & \multicolumn{2}{|c|}{ Standardized pages } \\
\hline & Count $^{\mathrm{b}}$ & $\operatorname{Rank}^{\mathrm{c}}$ \\
\hline 15 & $180 \cdot 59$ & 2 \\
\hline 12 & $91 \cdot 24$ & 19 \\
\hline 11 & $70 \cdot 41$ & 43 \\
\hline 10 & $186 \cdot 10$ & 1 \\
\hline 10 & $101 \cdot 72$ & 12 \\
\hline 10 & $66 \cdot 37$ & 53 \\
\hline 10 & 63.95 & 60 \\
\hline 10 & $54 \cdot 32$ & 96 \\
\hline 9 & 145.49 & 3 \\
\hline 9 & $124 \cdot 14$ & 7 \\
\hline 9 & $115 \cdot 08$ & 9 \\
\hline 9 & 96.67 & 15 \\
\hline 8 & $128 \cdot 64$ & 6 \\
\hline 8 & $105 \cdot 08$ & 10 \\
\hline 8 & $92 \cdot 99$ & 16 \\
\hline 8 & $91 \cdot 43$ & 18 \\
\hline 8 & $86 \cdot 59$ & 22 \\
\hline 8 & $85 \cdot 18$ & 26 \\
\hline 8 & $75 \cdot 35$ & 36 \\
\hline 8 & $71 \cdot 60$ & 42 \\
\hline 7 & $138 \cdot 59$ & 4 \\
\hline 7 & $122 \cdot 24$ & 8 \\
\hline 7 & $92 \cdot 64$ & 17 \\
\hline 7 & 85.97 & 24 \\
\hline 7 & $81 \cdot 52$ & 29 \\
\hline 7 & 75.95 & 34 \\
\hline 7 & $64 \cdot 89$ & 58 \\
\hline 7 & $60 \cdot 67$ & 69 \\
\hline 7 & $58 \cdot 26$ & 78 \\
\hline 7 & $57 \cdot 64$ & 82 \\
\hline 7 & $53 \cdot 70$ & 98 \\
\hline 7 & $30 \cdot 11$ & 304 \\
\hline 7 & $24 \cdot 22$ & 425 \\
\hline 7 & $21 \cdot 66$ & 510 \\
\hline 6 & $130 \cdot 63$ & 5 \\
\hline 6 & $89 \cdot 10$ & 20 \\
\hline 6 & $87 \cdot 65$ & 21 \\
\hline 6 & $85 \cdot 99$ & 23 \\
\hline 6 & $82 \cdot 08$ & 28 \\
\hline 6 & $75 \cdot 65$ & 35 \\
\hline 6 & $74 \cdot 72$ & 39 \\
\hline 6 & $74 \cdot 03$ & 40 \\
\hline 6 & $69 \cdot 59$ & 46 \\
\hline 6 & $66 \cdot 93$ & 52 \\
\hline 6 & $66 \cdot 31$ & 54 \\
\hline 6 & $64 \cdot 94$ & 57 \\
\hline 6 & $62 \cdot 38$ & 62 \\
\hline 6 & $62 \cdot 26$ & 64 \\
\hline
\end{tabular}

Table continued over page 
Table IV (Continued)

\begin{tabular}{lllccc}
\hline & & & \multicolumn{2}{c}{ Standardized pages } \\
\cline { 5 - 6 } Rank & Author & University & $\begin{array}{c}\text { Article } \\
\text { count }^{\mathrm{a}}\end{array}$ & Count $^{\mathrm{b}}$ & Rank $^{\mathrm{c}}$ \\
\hline 49 & Currie, Janet & U CA, Los Angeles & 6 & $58 \cdot 36$ & 77 \\
50 & Poterba, James M. & MIT & 6 & $56 \cdot 31$ & 86 \\
51 & Shiller, Robert J. & Yale & 6 & $54 \cdot 86$ & 92 \\
52 & Hsiao, Cheng & US CA, Los Angeles & 6 & $52 \cdot 36$ & 109 \\
53 & Whiteman, Charles H. & U Iowa & 6 & $49 \cdot 11$ & 126 \\
54 & Murphy, Kevin M. & U Chicago & 6 & $43 \cdot 64$ & 160 \\
55 & Maasoumi, Esfandiar & SMU & 6 & $42 \cdot 19$ & 166 \\
56 & Miron, Jeffrey A. & Boston U & 6 & $39 \cdot 47$ & 182 \\
57 & Caudill, Steven B. & Auburn U & 6 & $26 \cdot 72$ & 361 \\
58 & Fare, Rolf & Southern IL U & 6 & $25 \cdot 15$ & 401 \\
\hline
\end{tabular}

${ }^{a}$ Number of applied econometrics articles published in the 14 journals listed in Table I.

${ }^{\mathrm{b}}$ Standardized page count in applied econometrics based on the 14 journals listed in Table I.

${ }^{c}$ Applied econometrics rank in all 14 journals as reported in Table III.

Next, we focus on specific journals, namely Review of Economics and Statistics, American Economic Review, Journal of Business and Economic Statistics, Journal of Political Economy, Journal of Monetary Economics, Economic Journal and the Journal of Applied Econometrics. This controls for quality differences among journals but not for quality differences among articles within the same journal. These journals have more than $75 \%$ of their econometrics pages devoted to applied work (see Table I). Table $\mathrm{V}$ shows the top 20 universities by all econometrics publications by journal. This ranking is compared with the corresponding ranking in Table II using all 14 journals. In fact, 10 of the top 20 institutions publishing in the Review of Economics and Statistics are in the top 20 institutions ranked by all 14 journals considered. This is compared with 16 out of 20 institutions for the American Economic Review and Journal of Political Economy; 14 out of 20 institutions for the Journal of Monetary Economics; 13 out of 20 institutions for the Journal of Business and Economic Statistics; 7 out of 20 institutions for the Journal of Applied Econometrics and 5 out of 20 institutions for the Economic Journal.

Table VI lists individuals with three or more articles, by journal, over the period 1989-1995. Note that 13 out of the 21 individuals with three or more articles in the American Economic Review are among the top 100 ranked individuals by all 14 journals over the period 1989-1995. This compares with 9 out of 16 individuals for the Economic Journal and 12 out of 20 individuals for the Journal of Business and Economic Statistics. However, 19 out of 24 individuals with three or more articles in the Review of Economics and Statistics did not make the top 100 list of individuals in applied econometrics. This compares with one out of three individuals for the Journal of Monetary Economics, three out of four individuals for the Journal of Political Economy and two out of three individuals for the Journal of Applied Econometrics.

\section{CONCENTRATION RATIOS}

The field of applied econometrics seems to be highly concentrated based on the publications in the 14 journals considered over the period 1989-1995. In fact, the share of the top 10 universities in applied econometrics is $26 \%$. This compares to $31 \%$ for the field of economics over the period 1978-1983 (see Hirsch et al., 1984), and 22\% for the field of statistics over the period 1980-1986 
Table V. Top 20 universities by number of pages by journal, 1989-1995

\begin{tabular}{|c|c|c|c|c|c|}
\hline Journal & Rank & University & $\begin{array}{l}\text { Standardized } \\
\text { page count }^{\mathrm{a}}\end{array}$ & $\begin{array}{l}\text { Article } \\
\text { count }^{\text {b }}\end{array}$ & $\begin{array}{l}\text { All journals } \\
\text { rank }^{\mathrm{c}}\end{array}$ \\
\hline American Economic & 1 & Harvard & $312 \cdot 6$ & 23 & 3 \\
\hline \multirow[t]{19}{*}{ Review } & 2 & Princeton & $283 \cdot 5$ & 25 & 4 \\
\hline & 3 & Chicago & $249 \cdot 3$ & 24 & 1 \\
\hline & 4 & Northwestern U & $221 \cdot 0$ & 14 & 7 \\
\hline & 5 & MIT & $216 \cdot 3$ & 28 & 5 \\
\hline & 6 & U Pennsylvania & $208 \cdot 1$ & 21 & 2 \\
\hline & 7 & Michigan & $196 \cdot 8$ & 18 & 13 \\
\hline & 8 & Yale & $183 \cdot 8$ & 22 & 6 \\
\hline & 9 & UCLA & $162 \cdot 7$ & 12 & 28 \\
\hline & 10 & U CA, San Diego & $142 \cdot 3$ & 10 & 8 \\
\hline & 11 & New York University & $125 \cdot 9$ & 8 & 11 \\
\hline & 12 & Ohio State & $125 \cdot 7$ & 12 & 16 \\
\hline & 13 & Stanford & $109 \cdot 7$ & 11 & 9 \\
\hline & 14 & U Virginia & $102 \cdot 4$ & 6 & 34 \\
\hline & 15 & U CA, Berkeley & $89 \cdot 6$ & 14 & 17 \\
\hline & 16 & U CA, Davis & $88 \cdot 2$ & 8 & 19 \\
\hline & 17 & Rochester & $77 \cdot 8$ & 7 & 12 \\
\hline & 18 & Minnesota & $74 \cdot 5$ & 6 & 14 \\
\hline & 19 & U Wisconsin, Madison & $72 \cdot 9$ & 8 & 21 \\
\hline & 20 & Cornell & $70 \cdot 5$ & 4 & 27 \\
\hline \multirow[t]{20}{*}{ Economic Journal } & 1 & LSE, UK & $320 \cdot 0$ & 38 & 10 \\
\hline & 2 & Oxford U, UK & $194 \cdot 0$ & 16 & 22 \\
\hline & 3 & Cambridge U, UK & $146 \cdot 1$ & 14 & 29 \\
\hline & 4 & Birkbeck College, UK & $110 \cdot 4$ & 7 & 62 \\
\hline & 5 & U Warwick, UK & $106 \cdot 1$ & 12 & 42 \\
\hline & 6 & U Bristol, UK & $96 \cdot 2$ & 12 & 72 \\
\hline & 7 & Princeton & $88 \cdot 8$ & 4 & 4 \\
\hline & 8 & U College, London & $82 \cdot 0$ & 12 & 43 \\
\hline & 9 & U York, UK & $81 \cdot 8$ & 9 & 49 \\
\hline & 10 & MIT & $68 \cdot 1$ & 6 & 5 \\
\hline & 11 & U Manchester, UK & $55 \cdot 5$ & 13 & 144 \\
\hline & 12 & U Southampton, UK & $53 \cdot 6$ & 4 & 192 \\
\hline & 13 & U Pennsylvania & $49 \cdot 4$ & 5 & 2 \\
\hline & 14 & U Glasgow & $46 \cdot 8$ & 7 & 132 \\
\hline & 15 & Dartmouth College & $46 \cdot 6$ & 5 & 102 \\
\hline & 16 & U Essex, UK & $45 \cdot 1$ & 6 & 63 \\
\hline & 17 & U Groningen, Netherlands & $43 \cdot 7$ & 2 & 95 \\
\hline & 18 & U Newcastle Upon Tyne, UK & $42 \cdot 6$ & 4 & 122 \\
\hline & 19 & Carnegie-Mellon & $40 \cdot 6$ & 3 & 18 \\
\hline & 20 & U Reading & $39 \cdot 5$ & 3 & 159 \\
\hline Journal of Applied & 1 & Yale & $139 \cdot 8$ & 6 & 6 \\
\hline \multirow[t]{7}{*}{ Econometrics } & 2 & U CA, San Diego & $127 \cdot 2$ & 11 & 8 \\
\hline & 3 & U Wisconsin, Madison & $114 \cdot 4$ & 7 & 21 \\
\hline & 4 & Tilburg U, Netherlands & $96 \cdot 4$ & 11 & 50 \\
\hline & 5 & U Montreal, Canada & $93 \cdot 0$ & 7 & 32 \\
\hline & 6 & U Warwick, UK & $91 \cdot 8$ & 8 & 42 \\
\hline & 7 & U Iowa & $86 \cdot 2$ & 6 & 31 \\
\hline & 8 & Oxford U, UK & $80 \cdot 4$ & 5 & 22 \\
\hline
\end{tabular}

Table continued over page 
Table V (Continued)

\begin{tabular}{|c|c|c|c|c|c|}
\hline Journal & Rank & University & $\begin{array}{l}\text { Standardized } \\
\text { page count }^{\mathrm{a}}\end{array}$ & $\begin{array}{l}\text { Article } \\
\text { count }^{b}\end{array}$ & $\underset{\text { rank }^{\mathrm{c}}}{\text { All journals }}$ \\
\hline Journal of Applied & 9 & INSEE, France & $76 \cdot 2$ & 5 & 83 \\
\hline \multirow{11}{*}{ Econometrics (cont.) } & 11 & Princeton & $63 \cdot 6$ & 2 & 4 \\
\hline & 11 & Rochester & $63 \cdot 6$ & 3 & 12 \\
\hline & 11 & UCLA & $63 \cdot 6$ & 4 & 28 \\
\hline & 13 & LSE, UK & $62 \cdot 3$ & 5 & 10 \\
\hline & 14 & Minnesota & $60 \cdot 6$ & 3 & 14 \\
\hline & 15 & Cambridge U, UK & $58 \cdot 8$ & 4 & 29 \\
\hline & 16 & Stanford & $52 \cdot 8$ & 2 & 9 \\
\hline & 17 & Boston U & $51 \cdot 2$ & 4 & 30 \\
\hline & 18 & U Toronto, Canada & $50 \cdot 4$ & 4 & 24 \\
\hline & 19 & CREST, France & $48 \cdot 5$ & 4 & 185 \\
\hline & 20 & Erasmus U, Netherlands & $45 \cdot 8$ & 4 & 61 \\
\hline Journal of Business & 1 & Chicago & $157 \cdot 2$ & 17 & 1 \\
\hline Economics and & 2 & Princeton & 133.4 & 11 & 4 \\
\hline \multirow[t]{18}{*}{ Statistics } & 3 & N. Carolina State & $124 \cdot 7$ & 9 & 25 \\
\hline & 4 & Harvard & $114 \cdot 4$ & 13 & 3 \\
\hline & 5 & Queen's U, Canada & $94 \cdot 0$ & 8 & 54 \\
\hline & 6 & Northwestern U & $91 \cdot 4$ & 11 & 7 \\
\hline & 7 & Ohio State & $85 \cdot 3$ & 7 & 16 \\
\hline & 8 & U CA, San Diego & $81 \cdot 8$ & 10 & 8 \\
\hline & 9 & U Toledo & $80 \cdot 0$ & 7 & 73 \\
\hline & 10 & Minnesota & $79 \cdot 2$ & 9 & 14 \\
\hline & 11 & Southern Methodist U & $75 \cdot 4$ & 7 & 26 \\
\hline & 12 & U Toronto, Canada & $74 \cdot 0$ & 7 & 24 \\
\hline & 13 & Yale & $73 \cdot 1$ & 5 & 6 \\
\hline & 14 & LSE, UK & $72 \cdot 2$ & 10 & 10 \\
\hline & 15 & Hebrew U, Jerusalem & $69 \cdot 6$ & 6 & 57 \\
\hline & 15 & MIT & $69 \cdot 6$ & 7 & 5 \\
\hline & 17 & Carnegie-Mellon & $68 \cdot 4$ & 8 & 18 \\
\hline & 18 & U Pennsylvania & $64 \cdot 4$ & 7 & 2 \\
\hline & 19 & $\mathrm{U}$ of Texas, Austin & $61 \cdot 2$ & 6 & 15 \\
\hline & 20 & Indiana U & $59 \cdot 2$ & 6 & 41 \\
\hline Journal of & 1 & U Pennsylvania & $234 \cdot 2$ & 12 & 2 \\
\hline Monetary & 2 & Columbia & $165 \cdot 3$ & 10 & 20 \\
\hline \multirow[t]{14}{*}{ Economics } & 3 & Rochester & $158 \cdot 2$ & 10 & 12 \\
\hline & 4 & New York University & $156 \cdot 3$ & 10 & 11 \\
\hline & 5 & U CA, Berkeley & $121 \cdot 6$ & 9 & 17 \\
\hline & 6 & U CA, Davis & $103 \cdot 6$ & 6 & 19 \\
\hline & 7 & U Virginia & $96 \cdot 0$ & 5 & 34 \\
\hline & 8 & U Florida & $93 \cdot 1$ & 9 & 37 \\
\hline & 9 & Carnegie-Mellon & $91 \cdot 8$ & 5 & 18 \\
\hline & 10 & U Iowa & $77 \cdot 9$ & 9 & 31 \\
\hline & 11 & Minnesota & $70 \cdot 8$ & 5 & 14 \\
\hline & 12 & Harvard & $67 \cdot 6$ & 6 & 3 \\
\hline & 13 & U CA, San Diego & $64 \cdot 1$ & 4 & 8 \\
\hline & 14 & Chicago & $56 \cdot 5$ & 4 & 1 \\
\hline & 15 & Arizona State U & $55 \cdot 9$ & 7 & 60 \\
\hline & 16 & U British Columbia, Canada & $53 \cdot 2$ & 2 & 33 \\
\hline
\end{tabular}

Table continued on next page 
Table V (Continued)

\begin{tabular}{|c|c|c|c|c|c|}
\hline Journal & Rank & University & $\begin{array}{l}\text { Standardized } \\
\text { page count }^{\mathrm{a}}\end{array}$ & $\begin{array}{l}\text { Article } \\
\text { count }^{\mathrm{b}}\end{array}$ & $\begin{array}{c}\text { All journals } \\
\text { rank }^{\mathrm{c}}\end{array}$ \\
\hline Journal of Monetary & 17 & Yale & $52 \cdot 7$ & 4 & 6 \\
\hline \multirow[t]{3}{*}{ Economics (cont.) } & 18 & Stockholm U & $46 \cdot 9$ & 3 & 94 \\
\hline & 19 & Ohio State & $46 \cdot 6$ & 4 & 16 \\
\hline & 20 & Stanford & $46 \cdot 1$ & 4 & 9 \\
\hline Journal of Political & 1 & Chicago & $320 \cdot 8$ & 20 & 1 \\
\hline \multirow[t]{19}{*}{ Economy } & 2 & U Pennsylvania & $316 \cdot 2$ & 24 & 2 \\
\hline & 3 & MIT & $187 \cdot 9$ & 9 & 5 \\
\hline & 4 & Rochester & $181 \cdot 0$ & 9 & 12 \\
\hline & 5 & Harvard & $168 \cdot 3$ & 12 & 3 \\
\hline & 6 & Princeton & $138 \cdot 8$ & 9 & 4 \\
\hline & 7 & Stanford & $128 \cdot 3$ & 7 & 9 \\
\hline & 8 & Northwestern U & $108 \cdot 9$ & 8 & 7 \\
\hline & 9 & Yale & $92 \cdot 5$ & 7 & 6 \\
\hline & 10 & New York University & $87 \cdot 8$ & 9 & 11 \\
\hline & 11 & Michigan & $78 \cdot 6$ & 6 & 13 \\
\hline & 12 & Minnesota & $69 \cdot 9$ & 4 & 14 \\
\hline & 13 & U Toronto, Canada & $67 \cdot 9$ & 6 & 24 \\
\hline & 14 & U CA, San Diego & $67 \cdot 0$ & 6 & 8 \\
\hline & 15 & Texas A\&M University & $63 \cdot 7$ & 8 & 36 \\
\hline & 16 & Duke U & $57 \cdot 4$ & 5 & 23 \\
\hline & 17 & Columbia & $52 \cdot 5$ & 4 & 20 \\
\hline & 18 & Cornell & $47 \cdot 9$ & 4 & 27 \\
\hline & 19 & U of Texas, Austin & $47 \cdot 0$ & 3 & 15 \\
\hline & 20 & U CA, Davis & $46 \cdot 8$ & 5 & 19 \\
\hline Review of & 1 & U Pennsylvania & $153 \cdot 5$ & 18 & 2 \\
\hline Economics and & 2 & Ohio State & $132 \cdot 8$ & 17 & 16 \\
\hline \multirow[t]{18}{*}{ Statistics } & 3 & U CA, Berkeley & $125 \cdot 8$ & 17 & 17 \\
\hline & 4 & Penn State U & $120 \cdot 6$ & 13 & 35 \\
\hline & 5 & N. Carolina State & $116 \cdot 5$ & 17 & 25 \\
\hline & 6 & U of Texas, Austin & $114 \cdot 2$ & 12 & 15 \\
\hline & 7 & U Maryland & $113 \cdot 7$ & 15 & 47 \\
\hline & 8 & U CA, Davis & $109 \cdot 4$ & 14 & 19 \\
\hline & 9 & Harvard & $101 \cdot 5$ & 11 & 3 \\
\hline & 10 & New York University & $96 \cdot 5$ & 9 & 11 \\
\hline & 11 & Minnesota & $96 \cdot 2$ & 11 & 14 \\
\hline & 12 & MIT & $83 \cdot 4$ & 9 & 5 \\
\hline & 13 & U Pittsburgh & $79 \cdot 1$ & 10 & 40 \\
\hline & 14 & Yale & $77 \cdot 9$ & 10 & 6 \\
\hline & 15 & Texas A\&M University & $76 \cdot 0$ & 14 & 36 \\
\hline & 16 & Michigan State & $75 \cdot 8$ & 9 & 48 \\
\hline & 17 & U Georgia & $74 \cdot 1$ & 12 & 59 \\
\hline & 18 & U Illinois, Urbana & $73 \cdot 5$ & 10 & 39 \\
\hline & 19 & U Montreal, Canada & $70 \cdot 1$ & 13 & 32 \\
\hline & 20 & Iowa State & $69 \cdot 5$ & 12 & 58 \\
\hline
\end{tabular}

a Standardized pages of all econometrics articles in the designated journal.

${ }^{b}$ Number of all econometrics articles in the designated journal.

${ }^{c}$ Applied econometrics rank in all 14 journals as reported in Table II. 


\begin{tabular}{|c|c|c|c|c|c|c|}
\hline Journal & Rank & Author & University & $\begin{array}{l}\text { Standardized page } \\
\text { count }^{\mathrm{a}}\end{array}$ & $\begin{array}{l}\text { Article } \\
\text { count }^{b}\end{array}$ & $\underset{\text { rank }^{\mathrm{c}}}{\text { All journals }}$ \\
\hline \multirow[t]{21}{*}{$A E R$} & 1 & Card, David & Princeton & $56 \cdot 5$ & 6 & 18 \\
\hline & 2 & Blanchard, Olivier Jean & MIT & $55 \cdot 9$ & 5 & 111 \\
\hline & 3 & Borjas, George J. & U CA, San Diego & $51 \cdot 2$ & 4 & 57 \\
\hline & 4 & Heckman, James $\mathbf{J}$ & Chicago & $49 \cdot 2$ & 4 & 7 \\
\hline & 5 & Currie, Janet & UCLA & $45 \cdot 9$ & 4 & 77 \\
\hline & 6 & Ramey, Valerie A. & U CA, San Diego & $40 \cdot 6$ & 4 & 21 \\
\hline & 7 & Rosenzweig, Mark R. & U Pennsylvania & $32 \cdot 6$ & 4 & 2 \\
\hline & 8 & Murphy, Kevin M. & Chicago & $26 \cdot 8$ & 4 & 160 \\
\hline & 9 & Welch, Finis & Texas A\&M University & $19 \cdot 3$ & 4 & 264 \\
\hline & 10 & Angrist, Joshua D. & Hebrew U, Jerusalem & $66 \cdot 5$ & 3 & 3 \\
\hline & 11 & Blank, Rebecca M. & Northwestern U & $45 \cdot 9$ & 3 & 144 \\
\hline & 12 & Gruber, Jonathan & MIT & $36 \cdot 6$ & 3 & 140 \\
\hline & 13 & Mark, Nelson C. & Ohio State & $35 \cdot 9$ & 3 & 128 \\
\hline & 14 & Cecchetti, Stephen G. & Ohio State & $33 \cdot 3$ & 3 & 54 \\
\hline & 15 & Fair, Ray C. & Yale & 31.9 & 3 & 17 \\
\hline & 16 & Krueger, Alan B. & Princeton & $30 \cdot 6$ & 3 & 34 \\
\hline & 17 & Viscusi, W. Kip & Duke U & $29 \cdot 7$ & 3 & 26 \\
\hline & 18 & Kahn, Lawrence M. & U Illinois, Urbana & 21.9 & 3 & 175 \\
\hline & 19 & Levinsohn, James A. & Michigan & $21 \cdot 3$ & 3 & 64 \\
\hline & 20 & Slemrod, Joel & Michigan & $20 \cdot 6$ & 3 & 324 \\
\hline & 21 & Berry, Steven T. & Yale & $14 \cdot 6$ & 3 & 70 \\
\hline \multirow[t]{14}{*}{$E J$} & 1 & Pesaran, M. Hashem & Cambridge U, UK & $60 \cdot 5$ & 5 & 12 \\
\hline & 2 & Wadhwani, Sushil & LSE, UK & $41 \cdot 1$ & 5 & 42 \\
\hline & 3 & Nickell, Stephen J. & Oxford U, UK & $73 \cdot 1$ & 4 & 27 \\
\hline & 4 & Burgess, Simon M. & U Bristol, UK & $46 \cdot 3$ & 4 & 50 \\
\hline & 5 & Lee, Kevin C. & Cambridge U, UK & $42 \cdot 8$ & 4 & 94 \\
\hline & 6 & Alogoskoufis, George S. & Birkbeck College, UK & $53 \cdot 4$ & 3 & 49 \\
\hline & 7 & Wickens, Michael R. & U York, UK & $50 \cdot 3$ & 3 & 498 \\
\hline & 8 & van den Berg, Gerard J. & Free U, Amsterdam & $49 \cdot 9$ & 3 & 25 \\
\hline & 9 & Dolton, Peter J. & U Newcastle Upon Tyne, UK & $33 \cdot 8$ & 3 & 236 \\
\hline & 10 & Scott, Andrew & Oxford U, UK & $32 \cdot 2$ & 3 & 265 \\
\hline & 11 & Blanchflower, David G. & Dartmouth College & 31.4 & 3 & 279 \\
\hline & 12 & Hendry, David F. & Oxford U, UK & $28 \cdot 6$ & 3 & 15 \\
\hline & 13 & Machin, Stephen J. & U College, London & $24 \cdot 1$ & 3 & 191 \\
\hline & 14 & Oswald, Andrew J. & LSE, UK & $23 \cdot 1$ & 3 & 459 \\
\hline
\end{tabular}




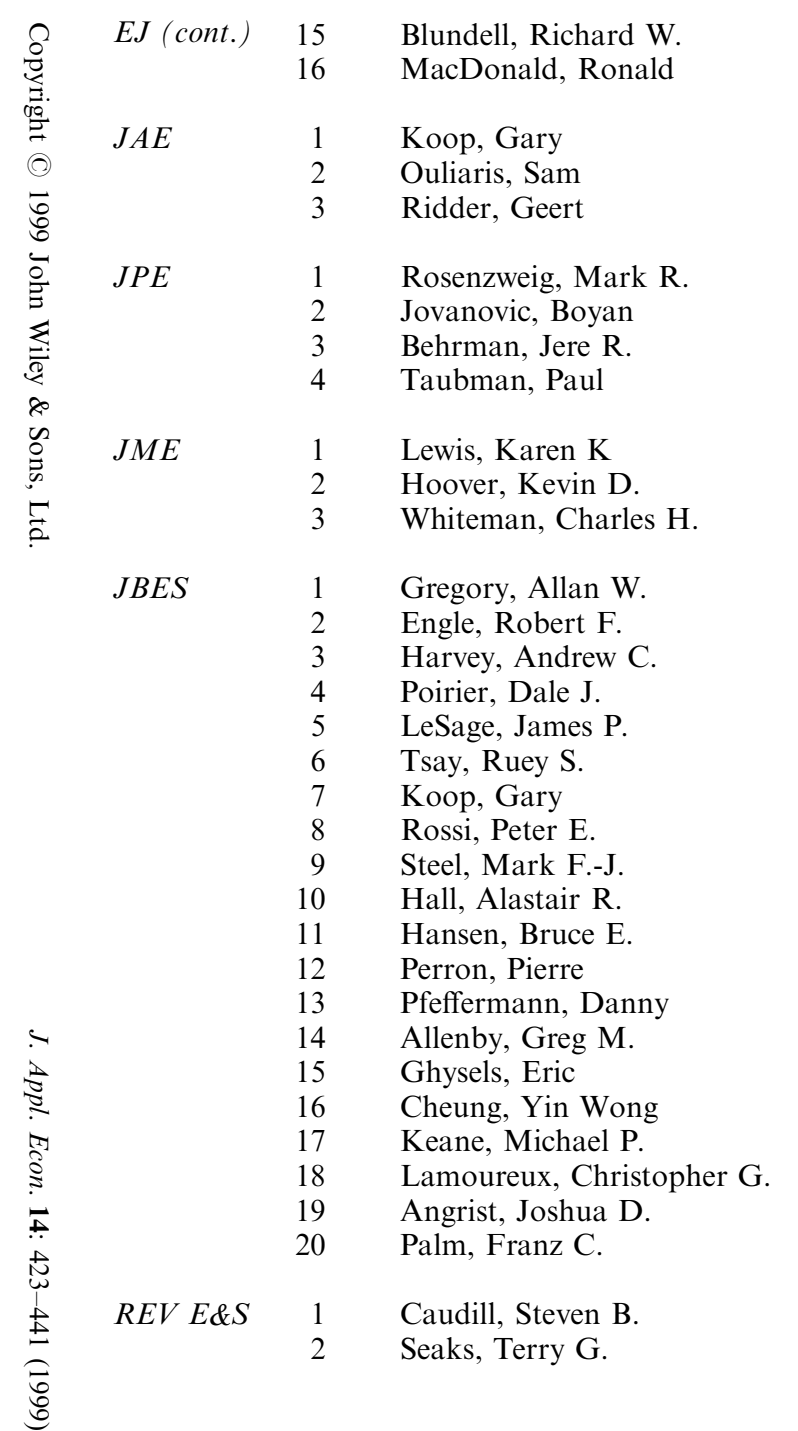

U College, London

U Strathclyde

U Toronto, Canada

Nat. U Singapore

Free U, Amsterdam

U Pennsylvania

New York University

U Pennsylvania

$85 \cdot 0$

U Pennsylvania

U Pennsylvania

U CA, Davis

U Iowa

Queen's U, Canada

U CA, San Diego

LSE, UK

U Toronto, Canada

U Toledo

Chicago

U Toronto, Canada

Chicago

Tilburg U

N. Carolina State

Boston College

U Montreal, Canada

U Jerusalem

Ohio State

U Montreal, Canada

U Calif., Santa Cruz

Minnesota

Washington U, St Louis

Hebrew U, Jerusalem

U Limburg, Netherlands

Auburn U

U NC, Greensboro 


\begin{tabular}{|c|c|c|c|c|c|c|}
\hline Journal & Rank & Author & University & $\begin{array}{l}\text { Standardized page } \\
\text { count }^{\mathrm{a}}\end{array}$ & $\begin{array}{l}\text { Article } \\
\text { count }^{b}\end{array}$ & $\underset{\text { rank }^{\mathrm{c}}}{\text { All journals }}$ \\
\hline$R E V E \& S$ & 3 & Bishop, John A. & E Carolina U & $10 \cdot 5$ & 4 & 510 \\
\hline \multirow[t]{21}{*}{ (cont.) } & 4 & Slesnick, Daniel T. & $\mathrm{U}$ of Texas, Austin & $50 \cdot 1$ & 3 & 1 \\
\hline & 5 & Fair, Ray C. & Yale & $43 \cdot 6$ & 3 & 17 \\
\hline & 6 & Shaw, Kathryn L. & Carnegie-Mellon & $36 \cdot 5$ & 3 & 47 \\
\hline & 7 & Holzer, Harry J. & Michigan State & $27 \cdot 2$ & 3 & 351 \\
\hline & 8 & Rosenthal, Stuart S. & U Brit. Columbia, Canada & $25 \cdot 0$ & 3 & 403 \\
\hline & 9 & Feinberg, Robert M. & American U & $24 \cdot 3$ & 3 & 421 \\
\hline & 10 & Kumbhakar, Subal C. & U of Texas, Austin & $19 \cdot 8$ & 3 & 36 \\
\hline & 11 & Wilson, Paul W. & U of Texas, Austin & $18 \cdot 6$ & 3 & 349 \\
\hline & 12 & LeSage, James P. & U Toledo & 18.4 & 3 & 46 \\
\hline & 13 & Baltagi, Badi H. & Texas A\&M University & $16 \cdot 9$ & 3 & 633 \\
\hline & 14 & Griffin, James M. & Texas A\&M University & $16 \cdot 9$ & 3 & 835 \\
\hline & 15 & Huffman, Wallace E. & Iowa State & $16 \cdot 7$ & 3 & 701 \\
\hline & 16 & Eckard, E. Woodrow, Jr & U CO, Denver & $16 \cdot 4$ & 3 & 708 \\
\hline & 17 & Herzog, Henry W. Jr. & U NV, Las Vegas & $14 \cdot 4$ & 3 & 838 \\
\hline & 18 & Schlottmann, Alan M. & U Tennessee & $14 \cdot 4$ & 3 & 838 \\
\hline & 19 & Schiantarelli, Fabio & Boston College & $13 \cdot 9$ & 3 & 390 \\
\hline & 20 & Terza, Joseph V. & Penn State U & $13 \cdot 3$ & 3 & 801 \\
\hline & 21 & Smith, V. Kerry & N. Carolina State & $12 \cdot 9$ & 3 & 306 \\
\hline & 22 & Lovell, C. A. Knox & U N. Carolina, Chapel Hill & $12 \cdot 2$ & 3 & 555 \\
\hline & 23 & Formby, John P. & U Alabama, Tuscaloosa & $9 \cdot 1$ & 3 & 425 \\
\hline & 24 & Thistle, Paul D. & Western MI U & $7 \cdot 6$ & 3 & 997 \\
\hline
\end{tabular}

${ }^{\mathrm{a}}$ Standardized pages of all econometrics articles in the deisgnated journal

${ }^{\mathrm{b}}$ Number of all econometrics articles in the designated journal. 
(see Phillips, Choi and Schochet, 1988). The top five universities in applied econometrics commanded a $15 \%$ share compared to $18 \%$ for econometric theory for the same period. This compares with $19 \%$ for economics and $13 \%$ for statistics for different periods. The concentration ratios for applied econometrics are close to those for all econometrics reported by Baltagi (1998, Table XI). The only exception is the share of the top university which is $3.5 \%$ for applied econometrics compared to $4.4 \%$ for all econometrics and $7.5 \%$ for econometric theory over the period 1989-1995. These compare with $5 \cdot 3 \%$ for economics and 3\% for statistics based on the above referenced studies.

\section{CONCLUSIONS}

The same caveat emphasized in the econometric theory rankings by Baltagi (1998) apply here. The choice of journals and the classification of applied econometrics articles are subjective. Applied econometricians do publish in other economics and applied statistics journals besides the ones included here. Econometricians also move across universities and this affects the university rankings. The conversion factors for the journals are subjective and do not reflect impact factors of these articles. Despite these shortcomings, we believe that these rankings are a useful guide to graduate students, faculty, and academic administrators.

\section{ACKNOWLEDGEMENTS}

The author would like to thank the editor M. Hashem Pesaran for entrusting me with this study; two referees for their helpful comments and P. M. Kisor for excellent research assistance.

\section{REFERENCES}

Baltagi, B. H. (1998), 'Worldwide institutional rankings in econometrics: 1989-1995', Econometric Theory, 14, 1-43.

Bairam, E. I. (1994), 'Institutional affiliation of contributors to top economic journals: 1985-1990', Journal of Economic Literature, 32, 674-679.

Conroy, M. E. and R. Dusansky (1995), 'The productivity of economics departments in the U.S.: Publications in core journals', Journal of Economic Literature, 33, 1966-1971.

Dusansky, R. and C. J. Vernon (1998), 'Rankings of U.S. economics departments', Journal of Economic Perspectives, 12, 157-170.

Hall, A. D. (1987), 'Worldwide rankings of research activity in econometrics: 1980-1985', Econometric Theory, 3, 171-194.

Hall, A. D. (1990), 'Worldwide rankings of research activity in econometrics: An update: 1980-1988', Econometric Theory, 6, 1-16.

Hirsch, B. T., R. Austin, J. Brooks and J. B. Moore (1984), 'Economics department rankings: Comment', American Economic Review, 74, 822-826.

Phillips, P. C. B., I. Choi and P. Z. Schochet (1988), 'Worldwide institutional and individual rankings in statistical theory by journal publications over the period 1980-1986', Econometric Theory, 4, 1-34.

Scott, L. C. and P. M. Mitias (1996), 'Trends in rankings of economics departments in the U.S.: An update', Economic Inquiry, 34, 378-400. 